\title{
Ultrastructure of house-dust mites, Dermatophagoides farinae and D. pteronyssinus*
}

\author{
Yasumasa ToNGU, ${ }^{* *}$ Akira IshiI ${ }^{* *}$ and Heinan $\mathrm{OH}^{* *}$ \\ Department of Parasitology, Okayama University Medical School. \\ Shikata-cho, Okayama 700, Japan
}

(Received: December 18, 1985)

Key words: ultrastructure, house-dust mite, Dermatophagoides farinae, Dermatophagoides pteronyssinus.

\begin{abstract}
The digestive tract of Dermatophagoides farinae and D. pteronyssinus was composed of pharynx, esophagus, anterior midgut, posterior midgut and hindgut. Among them the midgut had microvilli on the luminal surface of the epithelial cell. The food materials were wrapped up in a peritrophic membrane and forced to the hindgut. Microorganism was not found in the digestive tract of the mite maintained in our laboratory. Oil gland was a paired gland having the orifice at each side of posterior abdomen. This cell consisted of a single cell and contained fluid material in the lumen. Body cuticle was composed of 3 layers: epicuticle, exocuticle, and endocuticle. The endocuticle was the thickest, and was characterized by closely spaced lamellae structures. Many pore canals from epithelial cell ran through endocuticle to epicuticle. D. farinae and D. pteronyssinus described here did not have symbionts such as microorganism.
\end{abstract}

\section{INTRODUCTION}

Since the house dust mite, Dermatophagoides farinae and $D$. pteronyssinus have been known as an important inhalant allergen of bronchial asthma (Voorhorst et al., 1969; Ishii, 1975; Wharton, 1976; Lecks, 1973), the mite fauna in the house, especially in the house of asthmatic children was investigated by Takaoka et al. (1977) and Ishii et al. (1979), and anti-

* This investigation was supported by the Grant-in-Aid for Scientific Research from the Ministry of Education, Science and Culture of Japan (58480169).

** 頓宮廉正, 石井 明, 王 俩楠: 岡山大学医学部 寄生虫学教室（宁700 岡山県岡山市鹿田町 2-51) gen analysis of these mites have attracted special interests. Furthermore, rickettsia-like bodies were found in the gut of house dust mite in the house of Kawasaki disease patients (Hamashima et al., 1982). The house dust mite has been highlighted in the medical field. From this viewpoint, microorganisms in the mites become a serious matter of concern. However, there are few report on the ultrastructure of digestive truct of the mite except by Brody et al. (1972) and Wharton and Brody (1972). They used laboratory cultured mites, Dermatophagoides farinae. The present study was undertaken to visualize ultrastructural characteristics of the mite and to determine whether Dermatophagoides farinae and D. pteronyssinus which are maintained in our laboratory contain any microorganisms with special attention to the gut. 


\section{Materials and Methods}

The house dust mite, Dermatophagoides farinae and $D$. pteronyssinus, have been maintained in our laboratory at $25^{\circ} \mathrm{C}$ and $75 \%$ relative humidity (Sasa et al., 1970; Miyamoto et al., 1975). A mixture of an equal amount of powdered animal food (Clea Co., Tokyo) and dry yeast was sterilized by heating at $120^{\circ} \mathrm{C}$ for $1 \mathrm{hr}$, and was used for culture media of these mites.

Prior to fixation, each mite was punctured in 1 or more places to facilitate the penetration of reagents. The mites were prefixed in $2.5 \%$ phosphate buffered glutaraldehyde solution for $1 \mathrm{hr}$ at room temperature and then overnight in the new fixative solution in ice box. Following several changes of the buffer solution to rinse, the mites were postfixed in cacodylate buffered $1 \%$ osmium tetroxide for $2 \mathrm{hr}$ in ice box, dehydrated in a graded series of ethanol followed by $n$ buthylglycidyl ether, and embedded in epoxy resin. Sections were cut with a Reichert OmU2 ultramicrotome, double-stained with uranyl acetate and lead hydroxide, and examined with a Hitachi HS-8 electron microscope.

For light microscopy, fully engorged adult mites were fixed for $1 \mathrm{hr}$ in $70 \%$ alcohol, dehydrated in a graded ethanol series, and embedded in paraffin. Serial sections of $4 \mu \mathrm{m}$ thick were stained with haematoxylin and eosin. A full size image of alimentary tract was reconstructed from these serial sections.

\section{Results}

Diagramatic drawing of a digestive tract in Fig. 1 was reconstructed from serial paraffin sections of a fully engorged female, $D$. farinae. The digestive tract consisted of 3 parts: foregut, midgut, and hindgut. The foregut was composed of pharynx (Fig. 2) and esophagus (Fig. 3). The pharynx was lined with the cuticle about $0.5 \mu \mathrm{m}$ thick (Fig. 2, G) on the inner surface of a crescent lumen (Fig. 2, L). Well developed muscles (Fig. 2, Mu) were associated with dorsal pharyngeal wall.

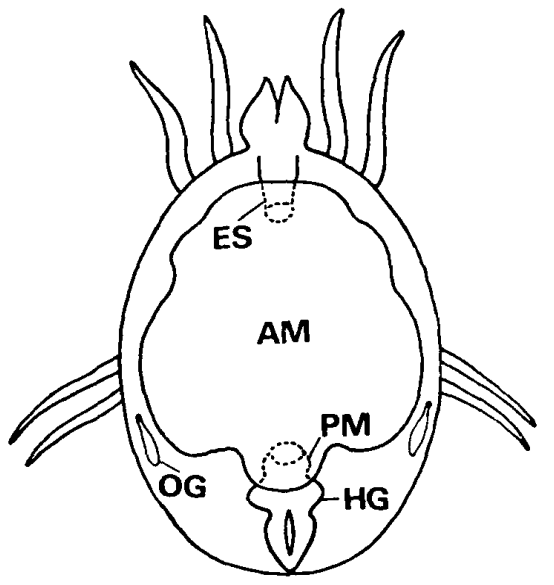

Fig. 1 Diagramatic drawing of digestive tract of fully engorged $D$. farinae.

ES, esophagus; AM, anterior midgut; PM, posterior midgut; $H G$, hindgut; $O G$, oil gland.

The esophagus (Fig. 3) arose from the pharynx passing by the brain region (Fig. 3, B). Its dorsal wall came in contact with the brain. The rugged lumen (Fig. 3, L) was lined by thin cuticle approximately 0.2 $\mu \mathrm{m}$ thick, and showed an 8-pointed star in the cross-section. The posterior region of the esophagus (Fig. 1, ES) was connected to the antero-ventral portion of the midgut.

The midgut consisted of an anterior (Fig. 1, AM) and posterior midgut (Fig. 1, PM). The former occupied the major part of engorged mite body, and the latter (Fig. 1, PM) was a small lumen connected to the posterior region of the anterior midgut. A single layered epithelial cells formed the midgut wall (Fig. 6, Me) and bore microvilli (Figs. 6, 7, 9, 12, Mv) on the luminal surface. In the anterior midgut, the epithelial cell (Fig. $7, \mathrm{Me}$ ) was very thin $(0.15$ $\mu \mathrm{m}$ at the thinest), had sparse microvilli (Fig. 7, MV), and often contained lipid-like dense droplets (Fig. 6, D) with a membrane and rough endoplasmic reticulum. In some portions the cell jutted into the gut lumen (Fig. 7, arrow), and finally floated freely in the lumen. These cells had many large vacuoles and electron dense cytoplasm, and showed a degenerating aspect. Furthermore, the cell-like bodies (Fig. 8) were in the anterior midgut lumen of conventionally cultured mites. These bodies that provided with an electron dense part in the center 
were wrapped by a peritrophic membrane. The epithelial cells in the posterior midgut were characterized by numerous microvilli (Fig. 9, Me) approximately $4 \mu \mathrm{m}$ in length. These microvilli were crowded together in contrast to those of anterior midgut.

The food ball (Fig. 9) of various sizes over $30 \mu \mathrm{m}$ surrounded by a peritrophic membrane (Fig. 9, Pm) $0.6 \mu \mathrm{m}$ thick was often noted in this region. This ball contained the food remnants, especially scraps of the cuticular structures (Fig. 9, arrow).

The hindgut (Fig. 1, HG) was a narrow and short tube from posterior midgut to the anus. The luminal surface was covered by the cuticle approximately $0.5 \mu \mathrm{m}$ thick (Fig. 10, Hc). Longitudinal folds of this cuticle ran the entire length of the anterior portion of the hindgut. The fecal materials wrapped by peritrophic membrane were observed in the hindgut lumen as in the case of posterior midgut. In the present study, microorganisms such as bacteriae were not observed in the gut of conventionally cul- tured mites.

Oil gland (Fig. 1, OG) was located on each postero-abdominal side of $D$. farinae and $D$. pteronyssinus. This gland was composed of a cell (Fig. 4) and its duct. This cell was a single cell, and lined by the cuticle (Figs. 4, 5, G) approximately $0.1 \mu \mathrm{m}$ thick on the luminal surface. Many mitochondria (Fig. 5, M) with well developed cristae and discontinuous membrane-like structures (Fig. 5, arrow) were distributed over the cytoplasm. The duct leading from the cell was opened on the cuticular surface of the mite, and the lumen was covered by undulating cuticle approximately $0.1 \mu \mathrm{m}$ thick. The lumen of the gland cells (Figs. 4, 5, L) was filled with homogeneous fluid materials.

The body cuticle that was of almost uniform thickness about $0.8 \mu \mathrm{m}$ consisted of electron dense epicuticle (Fig. 11, Epc), exocuticle (Fig. 11, Exc), and endocuticle (Fig. 11, Enc). The thick endocuticle was characterized by closely spaced lamellae

Fig. 2 Cross section of the pharynx of $D$. pteronyssinus associated with the muscle (Mu) at dorsal pharyngeal wall.

G, cuticle: L, lumen.

Fig. 3 Cross section of the esophagus of $D$. pteronyssinus.

B, brain; C, cuticle; L, lumen.

Fig. 4 Oil gland cell of $D$. farinae.

C, cuticle; E, epithelium; L, lumen.

Fig. 5 Oil gland cell of $D$. farinae.

The epithelial cell $(\mathrm{E})$ is covered the thin cuticle $(\mathrm{C})$, and contains many mitochondria (M) and membrane-like structures (arrows).

Fig. 6 Anterior midgut of $D$. farinae.

The epithelial cell (Me) bears microvilli ( $\mathbf{M v}$ ) on their luminal surface. Scraps of the cuticle (arrow) are seen in the lumen (L). D, lipid-like droplet.

Fig. 7 Anterior midgut epithelium (Me) of fully engorged $D$. farinae.

This epithelium is often jutted into the gut lumen (arrow). Mv, microvilli.

Fig. 8 Anterior midgut lumen of $D$. farinae.

The cell-like bodies are sometimes seen in the lumen.

Fig. 9 Posterior midgut of $D$. pteronyssinus.

The epithelial cell ( $\mathrm{Me}$ ) has many microvilli $(\mathrm{Mv})$. Food ball surrounded by a peritrophic membrane $(\mathrm{Pm})$ is situated in this lumen. Arrow, scraps of cuticle.

Fig. 10 Luminal surface of the rectum of $D$. farinae is lined by the cuticle $(\mathrm{Hc})$. L, lumen; Arrow, opening anus.

Fig. 11 Body cuticle of $D$. farinae.

The cuticle is consisted of epicuticle (Epc), exocuticle (Exc) and endocuticle (Enc.). E, epithelium.

Fig. 12 Midgut epithelium (Me) with microvilli (Mv). $\mathrm{L}$, lumen.

Fig. 13 Body cuticle of D. pteronyssinus.

The pore canals (arrows) run through the endocuticle. $\mathrm{Mu}$, muscle.

Bar is $1 \mu \mathrm{m}$ in each figure. 


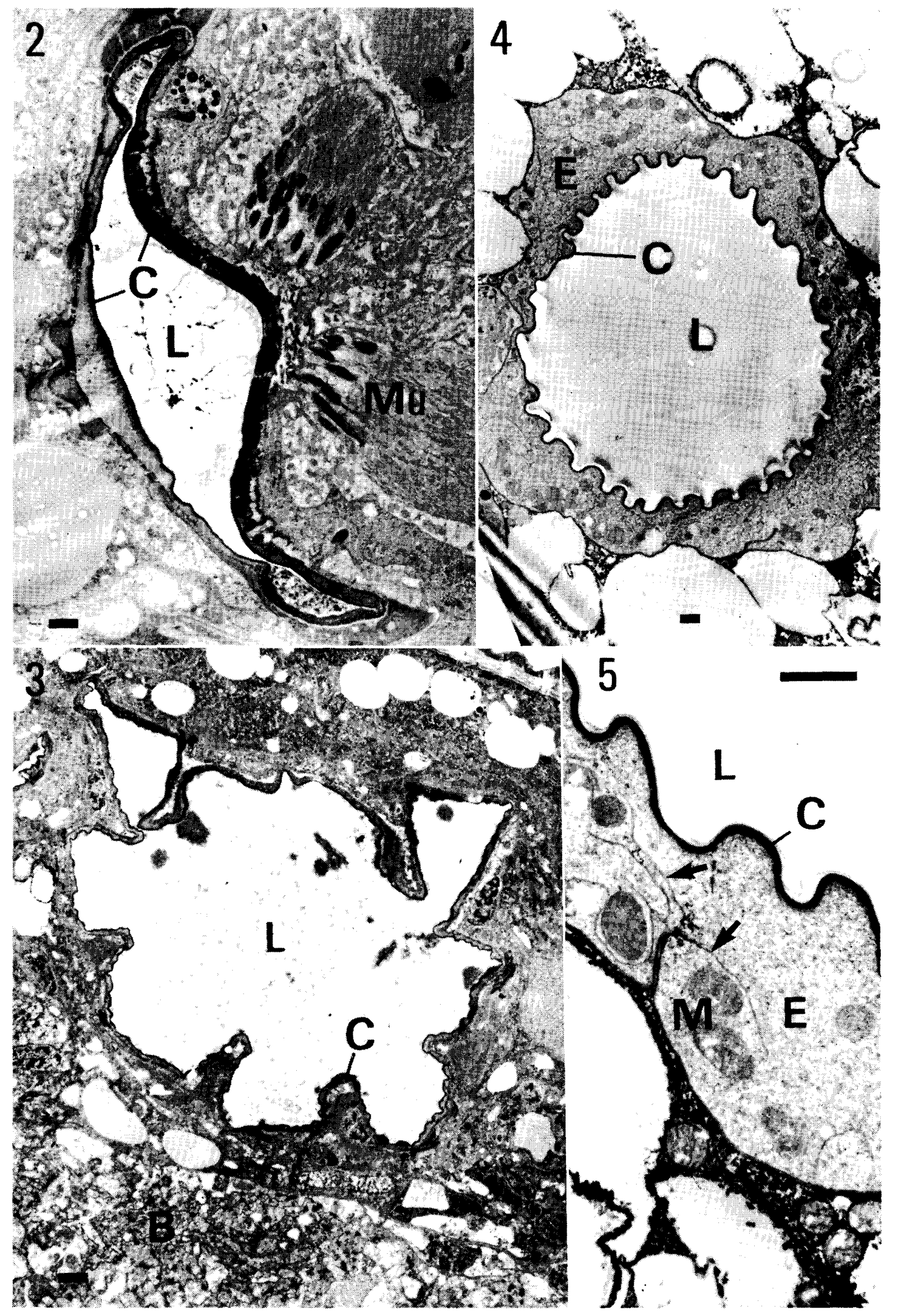

Figs. 2-5 


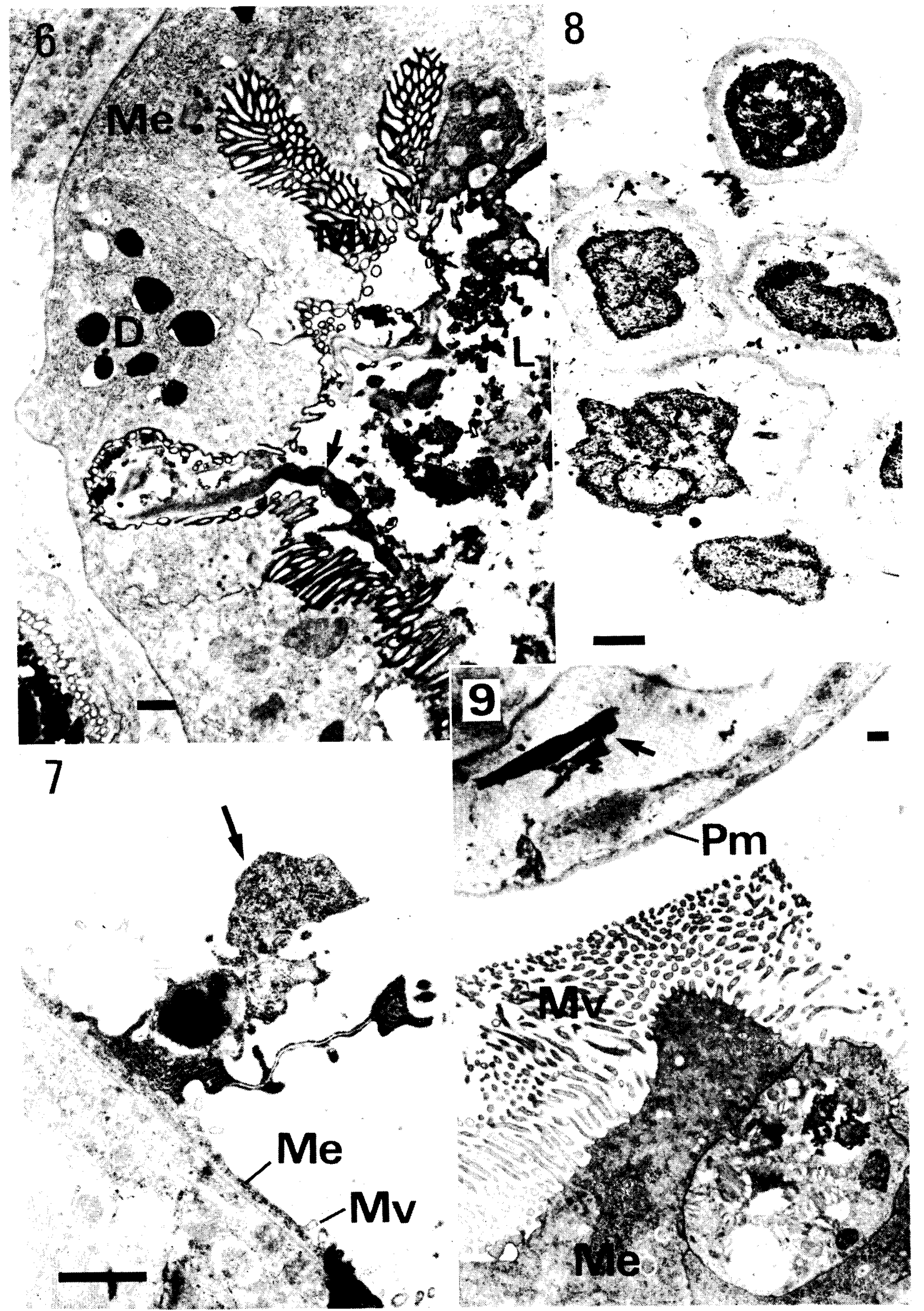

Figs. 6-9 


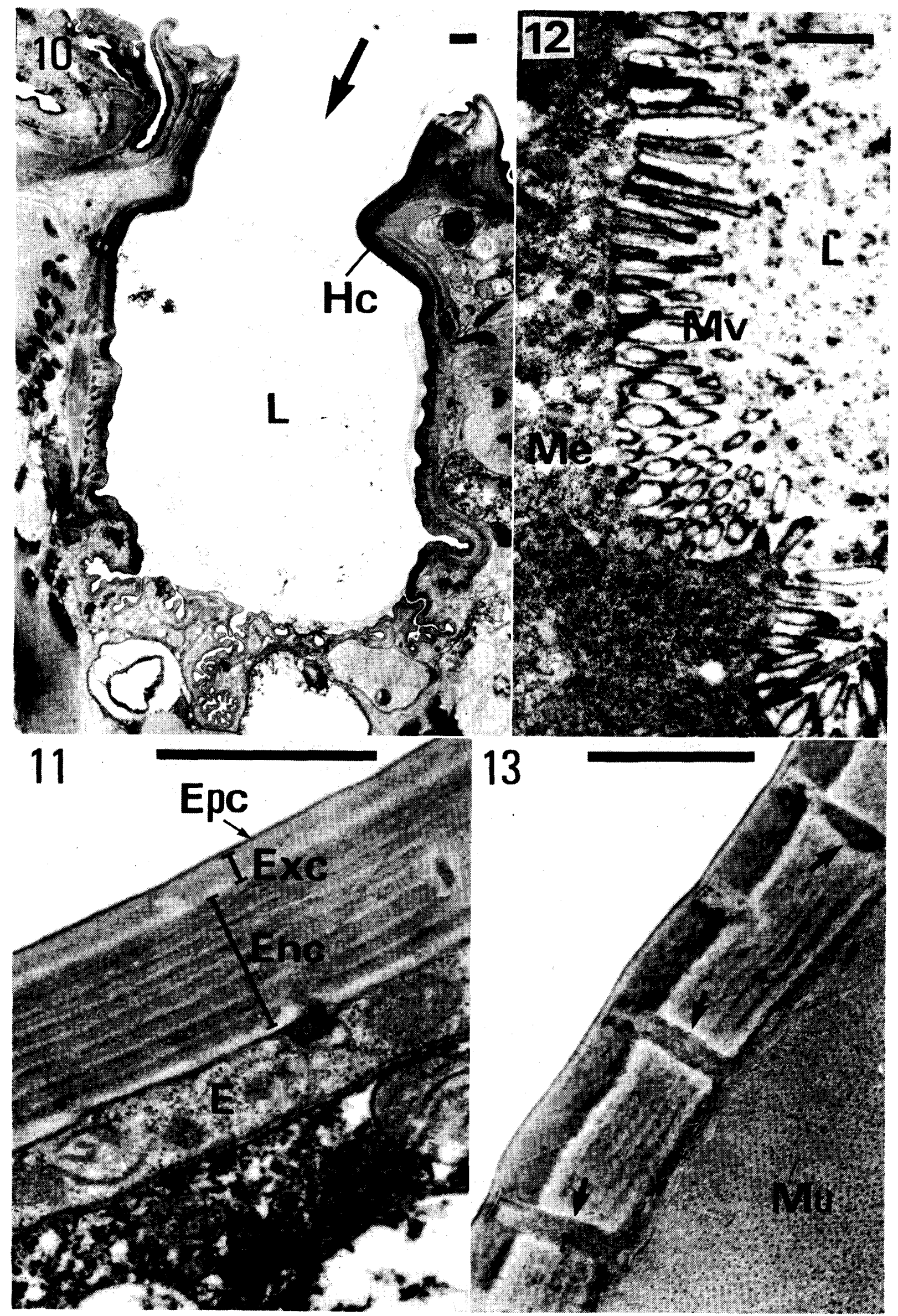

Figs. $10-13$ 
about 8 (Figs. 11, 13) for a distance of some $0.03 \mu \mathrm{m}$. The pore canals (Fig. 13, arrows) ran from the epithelial cell (Fig. $11, \mathrm{E})$ through endocuticle to a part of the way of the exocuticle. However, these canals were not opened through the outermost layer, epicuticle.

In the present study, using an electron microscope, the internal morphology revealed that there was no conspicuous difference between $D$. farinae and $D$. pteronyssinus.

\section{Discussion}

The digestive tract of the mite, Caloglyphus mycophagus, was described with a light microscope (Kuo and McCully, 1969; Kuo and Nesbitt, 1970). The electron microscopic observations of Dermatophagoides farinae was reported by Brody and Wharton (1970), Brody et al. (1972), and Wharton and Brody (1972). This species which was reduced to the verge of starvation was provided with 2 caeca of midgut (Brody et al., 1972). However, we were unable to identify remarkable caeca in fully engorged $D$. farinae and $D$. pteronyssinus as in the case of $D$. farinae by Brody et al. (1972). The gut contour seems to be influenced by conditions of the midgut that was engorged with food.

The thickness and aspect of the epithelial cell of the midgut were changed during digestion in Ornithodoros moubata (Akov, 1982) and Boophilus microplus (Agbede and Kemp, 1985). In the mite $D$. farinae, the midgut epithelium displayed an interesting variety of cell types (Brody et al., 1972). We also observed thin epithelial cells with a few, short microvilli in the anterior midgut and with many long microvilli in the posterior midgut. Furthermore, midgut wall sloughed off the epithelial cells into the lumen and these cells were decomposed as they did in the ticks (Akov, 1982; Agbede and Kemp, 1985). Above facts may indicate that the epithelial cells have a different function by their position in the midgut wall, and the presence of free epithelial cells in the lumen suggests that some enzymes for digestion are released together with their cells at a stretch in large quantities.
D. farinae had food balls which were surrounded by a peritrophic membrane in the posterior region of the midgut lumen (Wharton and Brody, 1972). In the present study, the formation of the food balls was also observed in D. farinae and D. pteronyssinus. These balls seem to contain the dregs of food, even fragments of other ingested mites, and to be forced to the rectum as a fecal pellet. According to Brody et al. (1972), most of $D$. farinae were cannibalistic. The presence of the cuticular fragments even in the gut of engorged mites supports their opinion.

Numerous microorganisms were found in the anterior midgut of cultured $D$. farinae by Brody et al. (1972) and in the digestive tract of house dust mites collected from the rooms of Kawasaki disease patients by Hamashima (1982) and Ushijima (1983). Rickettsia tsutsugamushi were identified in all tissues except the muscle of larval and adult Leptotrombidium arenicola by Wright et al. (1984). However, we were unable to detect any microorganisms or rickettsia in conventionally cultured $D$. farinae and $D$. pteronyssinus maintained in our laboratory. The above facts suggest that there is no symbiotic relation between microorganisms and these mites.

Oil gland of $D$. farinae was referred to as "lateral opisthosomal dermal glands" by Brody and Wharton (1970) using an electron microscope. They mentioned that the secretion from this organ probably contains a volatile portion and the repugnantorial function seems more probable. It has been known that $D$. farinae has alarm pheromon (Okamoto et al., 1978). The oil gland seems to serve for this purpose.

The fine structure of the cuticle of Laelaps echidnina was described by Wharton et al. (1968). They classified the cuticle into 3 layers: epicuticle, exocuticle, and endocuticle. The epicuticle was further divided into 3 parts: cement layer, wax layer, and cuticlin. Furthermore, they referred to lamelate layer as exocuticle. In our identification on the cuticle, this lamelate laver was regarded as the endocuticle. 


\section{REFERENCES}

Agbede, R. I. S. and D. H. Kemp (1985): Digestion in the cattle-tick Boophilus microplus: Light microscope study of the gut cells in nymphs and females. Int. J. Parasitol., 15: 147-157.

Akov, S. (1982): Physiology of Tickes, pp. 203205, Pergamon Press, Oxford.

Brody, A. R. and G. W. Wharton (1970): Dermatophagoides farinae: Ultrastructure of lateral opisthosomal dermal glands. Trans. Am. Microsc. Soc., 89: 499-513.

Brody, A. R., J. C. McGrath and G. W. Wharton (1972): Dermatophagoides farinae: The digestive system. N. Y. Entomol. Soc., LXXX: 152-177.

Hamashima, Y., K. Tasaka, T. Hoshino, N. Nagata, F. Furusawa, T. Kao and H. Tanaka (1982): Mites-associated particles in Kawasaki disease. Lancet, 2: 266.

Ishii, A. (1975): Research on the house dust mite and allergy in Japan. Jpn. J. Sanit. Zool., 26: 173-179 (in Japanese).

Ishii, A., M. Takaoka, M. Ichinoe, Y. Kabasawa and $T$. Ouchi (1979): Mite fauna and fungal flora in house dust from homes of asthmatic children. Allergy, 34: 379-387.

Kuo, J. S. and M. E. McCully (1969): Preparation of thin sections of mites for high resolution light microscopy. Can. J. Zool., 47: 737-740.

Kuo, J. S. and H. H. J. Nesbitt (1970): The internal morphology and histology of adult Caloglyphus mycophagus (Megnin) (Acarina: Acaridae). Can. J. Zool., 48: 505-518.

Lecks, H. I. (1973): The mite and house dust allergy. Clin. Pediatr., 12: 514-517.

Miyamoto, J., A. Ishii and M. Sasa (1975): A successful method for mass cuture of the house dust mites: Dermatophagoides pteronyssinus (Troussart, 1887). Jpn. J. Exp. Med., 45: 133-138.

Okamoto, M., K. Matsumoto, Y. Wada and N. Nakano (1978): Studies on antifungal effect of mite alarm pheromone Gitral. 1. Evaluation of antifungal effect of Citral. Jpn. J. Sanit. Zool., 29: 255-260 (in Japanese with English summary).

Sasa, M., J. Miyamoto, S. Shinohara, H. Suzuki and A. Katsuhata (1970): Studies on mass culture and isolation of Dermatophagoides farinae and some other mites associated with house dust and stored food. Jpn. J. Exp. Med.,
40: 367-382.

Takaoka, M., A. Ishii, Y. Kabasawa and T. Ouchi (1977): Mite fauna in house dust collected from the residence of asthmatic children. Jpn. J. Sanit. Zool., 28: 237-244.

Ushijima, H., P. Park, K. Yoshino, K. Ohta, R. Fujii and N. Kobayashi (1983): Microorganisms in house dust mites in Kawasaki disease. Acta Pediatr. Jpn., 25: 127-129.

Voorhorst, R., F. Th. M. Spieksma and H. Varekamp (1969): House-Dust Atopy and the House-Dust Mite, Stafleu's Sci. Publ. Co., Leiden, Netherlands.

Wharton, G. W. (1976): House dust mites. J. Med. Entomol., 12: 577-621.

Wharton, G. W., W. Parrish and D. E. Johnston (1968): Observations on the fine structure of the cuticle of the spiny rat mite, Laelaps echidnina (Acari-Mesostigmata). Acarologia, t. $\mathrm{X}$, fasc. 2, 206-214.

Wharton, G. W. and A. R. Brody (1972): The peritrophic membrane of the mite, Dermatophagoides farinae: Acariformes. J. Parasitol., 58: 801-804.

Wright, J. D., M. W. Hastriter and D. M. Robinson (1984): Observations on the ultrastructure and distribution of Rickettsia tsutsugamushi in naturally infected Leptotrombidium (Leptotrombidium). I. Med. Entomol., 21: 17-27.

\section{摘 要 \\ コナヒョウヒダニ Dermatophagoides farinae \\ およびヤケヒョウヒダニ D. pteronyssinus の微細構造}

継代飼育のヒョウヒダニの内部構造，上くに消化管 の微細構造を電子顕微鏡で観察した. 消化管は前腸, 中腸, 後腸からなり, 前腸と後腸は内腔面を薄いクチ クラがおおっている. 中腸はダニ体内の大部分を占有 乙前中腸と後中腸に分けられる. いずれも内腔面には 微絨毛が分布している. 1 層の中腸壁は部分的に細胞 が剝離し，内腔には food ball と称する膜に包まれた 食物残涬がみられる。しかし今回用いたダ二体内には 他の微生物は認められず，共生微生物は存在しないと 考えられる. oil gland は 1 個の細胞からなり, 細胞 内には腔所が形成され，分泌物が貯留されているもの と思われる. この腔所とそれから外部に開口寸る導管 の内面は薄いクチクラによっておおわれている．体表 のクチクラは epicuticle, exocuticle, endocuticle の 3 層からなり，多数の pore canal が epicuticleまで 走行している. 